\author{
Maksymilian Chutorański \\ Uniwersytet Szczeciński \\ maks1@poczta.onet.pl
}

\title{
Kolektyw edukacyjny 2.0. Między inspiracjami lekturą prac Makarenki a Latourem
}

\section{Summary}

Educational Collective 2.0. Between the inspirations of reading Makarenko and Latour

The text is devoted to the question of the contemporary relevance of - central to the Makarenko's pedagogy - the category of the collective. Confronting its understanding as developed by the Soviet pedagogue with researchers referring to the so-called "flat ontology", I develop a thesis that makes it possible to cross the dualistic way of thinking about culture and nature. Consequently, it allows the question concerning the "extended" non(only)human educational community to be posed.

Słowa kluczowe: A. Makarenko, B. Latour, kolektyw edukacyjny, pedagogika rzeczy, pedagogika nieantropocentryczna

Keywords: A. Makarenko, B. Latour, educational collective, pedagogy of things, nonanthropocentric pedagogy

Słynny kiedyś slogan „Przez kolektyw, w kolektywie, dla kolektywu!” jeśli jeszcze budzi jakieś skojarzenia u pedagogów, to nie są one najlepsze, m.in. pedagogiczny autorytaryzm, koszarowość, poświęcenie indywidualności wychowanków na rzecz narzuconego uczestnictwa w odgórnie mobilizowanym do działania zespole, ideologiczna dominacja jednego tylko punktu widzenia na świat. Wychowanie kolektywne stało się niemal synonimem tego wszystkiego, czego dzisiaj nie chcemy dla rozwijających się dzieci i dorosłych. Odwołując się do kategorii Foucaulta szybko zidentyfikujemy w pedagogii Makarenki procesy normalizacyjne, wszechobecność władzy dyscyplinarnej, które potrafimy tropić i piętnować także we współczesnych koncepcjach pedagogicznych. Co więcej, dzisiaj wyposażeni w różne narzędzia krytyczne umiemy identyfikować dużo subtelniejsze próby zniewolenia, wpisane również i w liberalne projekty edukacyjne podkreślające indywidualizm, humanizm i wolność.

Mój tekst jest paradoksalną próbą obrony tego zawołania, nie traktuję go jednak jak lekarstwa na indywidualizm, czy egoizm późnego kapitalizmu. Rozumienie kolektywu o które chodzi ma umożliwiać stawianie pytań o „poszerzoną” wspólnotę edukacyjną i nie(tylko)ludzką pedagogikę, będącą w stanie analitycznie rozpoznawać (na nowo splatać) złożone relacje między ludźmi i pozaludzkimi aktorami procesów edukacyjnych. Rozpocznijmy od postawienia pytań o granice pedagogicznej wyobraźni. 


\section{Nowoczesny kolektyw Makarenki}

Zdając sobie sprawę ze specyfiki pisarstwa radzieckiego pedagoga, w pracach którego, jak pisze Kwieciński, „trudno oddzielić fakty od zmyśleń” (Jaworska-Witkowska, Kwieciński 2011: 47), poniżej spróbuję scharakteryzować pedagogiczną wyobraźnię Makarenki i jej ograniczenia. Nawiązuję tu do Millsa i jego postulatu dotyczącego wyobraźni socjologicznej, którą utożsamiał ze ,zdolnością do przechodzenia z jednej perspektywy do innej - od politycznej do psychologicznej, od badania pojedynczej rodziny do porównawczej oceny budżetów krajów całego świata, od szkoły teologicznej do instytucji militarnej, od zagadnień przemysłu naftowego do studiów nad poezją współczesną" (Mills 2008: 54-55). Jego zdaniem próba rozumienia współczesności wymaga od badaczy poruszania się między wieloma poziomami rzeczywistości, łączenia „lokalnego konkretu” z ,,abstrakcyjnym systemem", codziennych doświadczeń z rozważaniami nad tym, co ogólne (zob. Abriszewski 2013; Nowak 2016).

Zatem interesuje nas to jak radziecki pedagog rozpoznaje złożoności procesów edukacji. Jaka jest podstawowa ontologia i teleologia kolektywu? Kto/co działa? Jacy są kluczowi edukacyjni aktorzy i charakter relacji między nimi? Jakie są granice, poza które myśl autora Poematu pedagogicznego wyjść się nie odważy?

Jednym z powodów, dla którego warto podjąć próbę przemyślenia kategorii kolektywu jest akcentowana w niej wychowawcza rola środowiska. Nie budzi wątpliwości radzieckiego pedagoga to, że wychowanie nie powinno ograniczać się do bezpośrednich oddziaływań wychowawcy na świadomość wychowanka, ale uwzględniać należy oddziaływania pośrednie (poprzez grupę). Dlatego tak ważna jest próba organizacji wychowującego otoczenia, a „decydujące znaczenie ma nie metoda poszczególnego nauczyciela i nawet nie metoda całej szkoły, lecz organizacja szkoły, kolektywu i pracy wychowawczej” (Makarenko 1988: 68). Ostatecznie chodzi nie o poszczególnych ludzi, ale o wychowanie całego kolektywu (Makarenko 1988: 17).

Czym zatem jest kolektyw? Makarenko odpowiada, że „to żywy organizm społeczny, który właśnie dlatego jest organizmem, że ma organy, że są w nim pełnomocnictwa, odpowiedzialność, wzajemne powiązania różnych części, współzależność: jeśli natomiast tego wszystkiego brak, to nie ma również kolektywu, a jest tylko tłum lub zbieranina ludzka" (Makarenko 1988: 16). Kolektyw jest grupą społeczną, w której króluje porządek, która jest optymalnie, hierarchicznie zorganizowana (dyscyplina, organy, funkcje), podporządkowana celom społeczno-politycznym i w której panuje wspólny pogląd na świat. Grupę jednoczy wspólny cel, wspólna praca, wspólna organizacja (Kamiński 1948: 61).

Interesująco przedstawia się rozumienie indywidualnych różnic między ludźmi tworzącymi ten „społeczny organizm, z kierownictwem na czele” (Kamiński 1948: 61). Makarenko widzi postać i rolę nauczyciela jako element większej całości organizującej dopiero jego miejsce. Jak pisze „Trzeba, żeby w kolektywie był też gniewny, surowy dziad, który nikomu niczego nie wybacza, który nikomu nigdy nie ustępuje. Trzeba, żeby była też »łagodna dusza« - człowiek o nieco słabszej woli, który wszystkich kocha, wszystkim 
wszystko wybacza, wszystkim stawia piątki [...] Słowo honoru - pisze radziecki pedagog - taki jest potrzebny" (Makarenko 1988: 17). Nie tyle dyspozycje poszczególnych wychowawców decydują o sukcesie wychowawczym, co wzajemne relacje i sprzężenia między członkami zespołu i relacje, w jakie kolektyw wchodzi z otoczeniem. Porządek, o który chodzi, zapowiedziany jest na poziomie wyższym niż indywidualny. Jedność organizacji pracy zespołu wychowawczego powiązana jest z jednością organizacji szerszego systemu społecznego (nad którą „,czuwają” organy partii będące awangardą kierującą „kolektywem kolektywów”).

I w odniesieniu do rzeczy widoczna jest potrzeba wprowadzenia ładu w życie zbiorowości. „Uporządkowane sprawy materialne znacznie ułatwiają całą robotę $[\ldots]$ materialna strona życia uczy kolektyw przystosowywania się do ogólnych warunków gospodarczych, zaznajamia go z zasadami kolektywnej odpowiedzialności; tu właśnie można znaleźć wiele tematów do ćwiczenia się wychowanków w dziedzinach mających znaczenie dla dobra kolektywu" (Makarenko 1988: 150). Materialności mają znaczenie, bo odpowiednio dobrane wpływają na wygodę życia wychowanków, porządek i czystość, umożliwiają kształtowanie odpowiednich nawyków, dzięki nim „tworzy się spokojniejsze tło dla nastroju psychicznego wychowanków" (Makarenko 1988: 150).

Przypisywanie dużej wagi środowisku, wzajemnym połączeniom pomiędzy oddziałującymi na siebie aktorami to kluczowe założenie dla naszej próby rehabilitacji Makarenkowskiego sloganu. Dlaczego jednak opisane powyżej rozumienie kolektywu jest dla nas nie do przyjęcia? Jak sądzę, dominujący sposób krytyki pomysłów kierownika kolonii im. Dzierżyńskiego, na którego elementy zwróciłem uwagę na początku tekstu, wiąże się z podkreślaniem braku humanizmu. My jednak postąpimy nieco inaczej. Makarenkowski kolektyw oskarżymy o to, że jest zbyt humanistyczny, w sensie: zbyt mocno akcentuje antropocentryczne założenia o wyjątkowości (poznawczej, sprawczej) człowieka i wiarę w jego niemal nieograniczone możliwości kształtowania swoich warunków życia.

Kwa wskazuje dwie tradycje rozumienia złożoności w nauce: romantyczną i barokową. Każda z nich odwołuje się do innej koncepcji struktury rzeczywistości. Romantycznie rozumiana złożoność zakłada podkreślenie i poszukiwanie ukrytej ,jedności w całości” - wiąże się z wskazywaniem jednoczącej działanie poszczególnych elementów zasady organizującej (wiodąca metafora to organizm). „Romantyczny holizm integruje jednostki, które wydają się być niejednorodną wielością na poziomie fenomenologicznym do pojedynczego podmiotu na wyższym poziomie organizacji” (Kwa 2002: 25). Jednostki wyższego rzędu mogą mieć abstrakcyjne struktury. Barokowe rozumienie złożoności natomiast otwarte jest na wielogłosowość, ścieranie się i sprzężenia lokalnych logik, aktorów i procesów. Uznanie złożoności wiąże się tu z otwarciem na polifonię, „,współpracę”, a porządek wyłania się niejako „od dołu”, często z logik przeciwstawnych strategii. Nowak „romantyczną” wizję złożoności społecznej łączy z charakterystycznym jej ujmowaniem w paradygmacie funkcjonalistyczno-cybernetycznym (cybernetyka, Parsons, Luhmann), zaś złożoność rozumianą na sposób (neo)barokowy z paradygmatem systemowo-historycznym (Braudel, Wallerstein Latour, Deleuze) (Nowak 2011). 
Zachowując ten podział, kolektyw Makarenki można przypisać do podejścia romantycznego. Nawet jeśli uznaje się tu, że wychowuje całe otoczenie, że grupa może stanowić układ zapewniający pośrednie oddziaływanie stymulujące rozwój dziecka to jednak gwarantem sukcesu pedagogicznego jest plan i synchronizacja. Daje się zaliczyć takie rozumienie zbiorowości do opisanych przez Krajewskiego polityk prostoty, które są kompleksami działań, idei, rozwiązań technicznych mającymi podtrzymywać modernistyczne przekonanie o możliwej nieograniczonej kontroli człowieka nad rzeczywistością (Krajewski 2013: 40, zob. też Urry 2005; Mason 2008).

Kwestionowanie złożoności widoczne jest w pracach Makarenki na wielu poziomach (etycznym, sprawczym, organizacyjnym). Zbyt ufając kierowaniu, nie jest on w stanie docenić rozwojowych potencjałów tych niestabilności, które wprowadzane są przez „doły”, traktując je jako zagrożenie dla optymalnego uporządkowania. Makarenko nie jest w stanie dostrzec kolektywów jako dynamicznych samoorganizujących się układów (Prigogine, Stengers 1990).

Mimo że radziecki pedagog zdaje się doceniać rolę nie(tylko)ludzkiego środowiska, w tym materialności w procesie wychowania, to rzeczy są jednak rozumiane jako środek niebędący w stanie wnieść nowej jakości w relacje społeczne. Kolektyw musi brać pod uwagę „sprawy materialne” (ubrania, narzędzia, przedmioty do higieny etc.), jednak jego budulec stanowią relacje między ludźmi, a „społecznym klejem” są przede wszystkim utrwalone tradycje, zwyczaje („osiągnięcia kolektywu”), ideologiczna perspektywa, instytucje/organy etc. Takie rozumienie zbiorowości nie pozwala dostrzec armii nieludzkich budowniczych kolektywu, tu rozumianych jako bierne, nieme narzędzia w rękach ludzi, nieproblematyczne zapośredniczenie ich woli.

Proponuję dokonać kilku nieantropocentrycznych korekt w rozumieniu kolektywu przez Makarenkę. Pierwsza korekta dotyczy zmiany w rozumieniu sprawczości i uznania, że są pozaludzcy aktorzy, którzy aktywnie uczestniczą w procesach wychowania. Druga wiąże się z przyjęciem bardziej barokowego rozumienia złożoności zjawisk edukacyjnych i większym pluralizmem w wyznaczaniu granic i celów edukacyjnych zbiorowości.

\section{Więcej niż ludzki kolektyw edukacyjny}

Myślenie o człowieku jako części środowiska, z którym łączą go symetryczne, złożone relacje, doczekało się wielu różnych rozwinięć. Akcentowane w ramach nieantropocentrycznej humanistyki posthumanizm i „zwroty” (,zwrot ontologiczny” „ku rzeczom”, „środowiskowy”, „ku sprawczości”) są odpowiedzią na nowe wyzwania (bio-technologiczne i ekologiczne) wymykające się analitycznie tradycyjnej refleksji humanistycznej, oddzielającej świat natury od świata kultury, podmioty od przedmiotów. Zdaniem Latoura nowoczesne społeczności na poziomie autorefleksji oczyszczają wspólnotę ludzi (proces puryfikacji) z hybrydycznych bytów. Tworzą tym samym „ślepą plamkę" epistemologiczną sprzyjającą niekontrolowanemu tworzeniu się powiązań ludzi i nieludzi (Latour 2011). 
Edukacja (i społeczeństwo w ogóle) od zawsze wiązała ze sobą/była wiązaniem ludzi (uczniowie, nauczyciele, rodzice) i nieludzi (przedmioty, budynki, zwierzęta), jednak dzisiaj sieci wzajemnych powiązań stają się coraz dłuższe (globalne, czy nawet kosmiczne). Poszczególne sfery życia coraz rzadziej daje się rozumieć jako autonomiczne (mniej lub bardziej niepowiązane ze sobą) elementy/praktyki, częściej jako sieć złożonych zależności. Dzięki technologii kupować można z domu, telefon z pracy odebrać na wczasach, mail do klienta napisać w niedzielę, na tym samym portalu społecznościowym można umieścić zdjęcia swoich dzieci i zorganizować grupę pracującą nad projektem zleconym przez szefa. Tabletki przeciwbólowe i inne substancje chemiczne pozwalają zapanować nad bólem zakłócającym naukę, dzięki nim możemy zapomnieć o śnie do chwili napisania artykułu naukowego. „Technologie, artefakty i rozstrzygnięcia medyczne są także wehikułami rozstrzygnięć politycznych, narzędziami władzy i opresji, zaskakującymi członkami zbiorowości, które współtworzą polis, działając i wprowadzając różnicę. Wirusy i ekosystemy wchodzą z nami w interakcje, które redefiniują problemy uznawane dotąd za wyłącznie ludzkie" (Bińczyk 2012: 320).

Rzeczy, zwierzęta, i inni nie-ludzie odgrywają rozmaite role w procesach edukacyjnych (najczęściej więcej niż jedną w tym samym czasie). Ich pracy często nie sposób zastąpić pracą wychowawców, np. nie można sobie „wyobrazić” rzeczy w montessoriańskiej edukacji i tym sposobem pozbyć się ich fizycznej obecności z przestrzeni przedszkola, bez zmiany samej praktyki (zob. Abriszewski i inni 2017; Chutorański Makowska 2016; Chutorański 2016, 2017). Samo uczenie jest procesem emergentnym, wiąże się ze wspólną ewolucją jednostek i całego środowiska (Morison 2008: 22), nie dzieje się jedynie w głowach uczniów (ludzi): myślimy za pomocą przedmiotów, poprzez manipulację nimi (poznanie jest ucieleśnione) (Kirsh 2013). Rzeczy zatem nie są na „zewnątrz” edukacyjnych zbiorowości, są warunkiem ich trwałości, wymuszają zmiany.

W tym kontekście zasadne jest pytanie o możliwość śledzenia bytów, zapośredniczeń, i mediatorów ${ }^{1}$ przekształcających działanie pedagogiczne, zmieniających edukacyjną wspólnotę, jej aksjologię i politykę. Jak poszerzyć rozumienie tego, co edukacyjne? W jaki sposób uczynić nieludzkich aktorów procesów edukacyjnych widzialnymi? Inspirowani przede wszystkim teorią aktora-sieci spróbujmy dać jedną z możliwych odpowiedzi.

Jeśli odpowiadając na pytanie „Jak działa społeczeństwo/edukacja?” redukcjonista humanistyczny będzie starał się określić kierunek determinacji przebiegający od tego, co

1 Co różni pierwsze od drugich? Zapośredniczeniem jest „to, co przenosi znaczenie lub siłę bez przekształceń: określenie jego danych na wejściu (inputs) wystarcza do określenia jego danych na wyjściu (outputs). [...] pośrednika potraktować można nie tylko jako czarną skrzynkę, ale także jak czarną skrzynkę, która stanowi jedność, nawet jeśli wewnętrznie składa się z wielu części” (Latour 2010: 56). Natomiast „,mediatorów nie da się po prostu potraktować jako jedno [...] Ich wejście nie jest nigdy dobrym wskaźnikiem wyjścia; ich specyficzność musi być brana pod uwagę za każdym razem. Mediatorzy przekształcają, thumaczą, zakłócają i modyfikują znaczenia czy elementy, które mają przenieść”(Latour 2010: 56). Kiedy relacje są stabilne, a działanie wywołuje przewidziane skutki, mamy do czynienia z jego pośredniczeniem, kiedy pojawiają się konsekwencje, których nie przewidywaliśmy, a rzecz „zachowała się” w sposób nieprzewidywalny działanie zostało mediowane przez element sieci. 
kulturowe (to, co materialne podporządkowane jest temu, co społeczne, rzeczy są ucieleśnieniem dyskursywnych logik władzy etc.), a naturalista uzna, że to, co społeczne jest podporządkowane temu, co materialne, to badacze odwołujący się do teorii aktora-sieci zachowują ostrożność i nie wskazują ostatecznych kierunków determinacji. Interesy, wartości, władza, ideologie traktuje się tu nie jako wyjaśnienie stosunków społecznych, ale jako coś, co samo wymaga wyjaśnienia.

Dlatego wprowadzone przez autora Nadziei Pandory pojęcie zbiorowości czy też kolektywu ${ }^{2}$ ma zastąpić obecne $\mathrm{w}$ tradycyjnych teoriach społecznych pojęcie społeczeństwa jako „zbudowanego z tego, co społeczne” (,sił społecznych”, wartości, więzi etc.), ma podkreślać symetrię między człowiekiem a czynnikami pozaludzkimi. Społeczeństwa możliwe są dlatego, że ludzie tworzą równocześnie relacje między sobą oraz niezliczoną liczbą rzeczy, które często okazują się twardszym spoiwem niż więzi między ludźmi (zamek w drzwiach stanowi lepszą gwarancję obowiązywania normy wartości prywatnej niż ustne zapewnienia sąsiadów, pogotowie ratunkowe tak samo jak wykwalifikowanych ratowników medycznych potrzebuje szybkich i dobrze wyposażonych karetek).

Takie podejście wiąże się z przyjęciem ontologii relacyjnej (Abriszewski 2012; Bińczyk 2007) zakładającej, że każdy obiekt jest wyznaczany poprzez swoje relacje z innymi obiektami. Relacji nie należy utożsamiać jedynie z relacjami społecznymi (sieci są socjotechniczne, zarazem społeczne, techniczne, naukowe, ekonomiczne etc.) (Latour 2011). Zamiast przypisywania sprawstwa jedynie ludziom traktuje się je jako rozproszone - atrybut „powiązań bytów". Zamiast o podmiotach (ludziach) mówi się tu o aktorach. Aktor jest czymś co działa, jest względnie ustabilizowanymi relacjami (aktor zawsze jest siecią, sieć jest aktorem). Żadnemu z działających nie przypisuje się a priori wyróżnionego miejsca w sieciach sprawstw (dopiero badanie konkretnych sieci relacji może przynieść w tej kwestii lokalne rozstrzygnięcia). Nie chodzi jednak o przyznanie „wszystkich możliwych cech wszystkim bytom, o zrównania ludzi i rzeczy czy ludzi i zwierząt. Chodzi jedynie o pewien empiryzm i agnostycyzm badacza - ten nie zakłada z góry, w jaki sposób badany świat jest zbudowany. Powiedzą mu to dopiero (inspiracja etnometodologią) badani aktorzy. To oni sami muszą świat zaludnić i zdecydować co jest fikcją, a co faktem" (Abriszewski 2010: X-XI).

Odwołanie do ANT pozwala przekroczyć wyobraźnię Makarenki. Żaden kolektyw edukacyjny nie jest zbudowany z „pedagogicznego tworzywa”, jedynie z intencji wychowawców i świadomych, celowych, organizowanych oddziaływań ludzi (Chutorański 2017). Wprowadzenie nowych przedmiotów w relacje edukacyjne nigdy nie jest niewinne.

\footnotetext{
2 Collective - przekładane jest przez tłumaczy zarówno jako kolektyw (Latour 2009), jak i zbiorowość (Latour 2010). Abriszewski tak tłumaczy swoje rozstrzygnięcie translacyjne: „Kuszącą alternatywą translacyjną wydawał się »kolektyw«, zwłaszcza poprzez analogię do Fleckowskich »kolektywów myślowych«. Jednakże tutaj wyłaniały się również niebezpieczeństwa: słowo »kolektyw« jest obciążone negatywnymi, poprzedniosystemowymi skojarzeniami i przywodzi na myśl niewielką grupę osób, a nie olbrzymie masy ludzi i czynników poza-ludzkich" (Abriszewski 2010:XXXI-XXXII). Można powiedzieć, że to, co było powodem przyjęcia „zbiorowości” dla Abriszewskiego dla mnie było powodem pisania raczej o kolektywie w ramach tego tekstu. Chodziło właśnie o wskazanie na łączność z pedagogią Makarenki w „systemowym” rozumieniu edukacji (tyle że oczywiście inaczej przeze mnie rozumianym).
} 
Rzeczy robią różnicę, ułatwiając lub utrudniając określone praktyki nauczycieli, uczniów i rodziców. Warto pytać, jak to się dzieje, że niektóre relacje się stabilizują, jak długie sieci tworzą (Co w tym pomaga? Co wymusza zmiany? Jacy ludzie? Jakie rzeczy?). Wyjście od relacji, a nie od (dobrze rozpoznawanych i oczywistych) aktorów oznacza, że nie warto jak Makarenko zbyt wcześnie podejmować decyzji dotyczącej tego, kto tworzy kolektyw edukacyjny, np. poprzez wskazanie grupy uczniów zespołu klasowego.

Ocieplenie klimatu, kwestie związane z transportem dzieci do szkoły, topografia terenu i architektura, szczepienia, opieka zdrowotna etc. traktowane są najczęściej jako „mglisty" kontekst lub kwestie związane z dydaktycznym doborem edukacyjnych treści. Tymczasem spóźniające się autobusy, które dowożą dzieci z małych miejscowości do szkoły mogą mówić o inkluzywności edukacji i relacjach uczniowskich nie mniej niż programy kształcenia i postawy nauczycieli. W edukacji lokalnie i konkretnie wchodzą w relacje różni aktorzy. Szczepienia mogą się tu mieszać z nauką pisania i z rodzicami komentującymi rzeczywistość na forach internetowych, lekcje muzyki mogą wchodzić w relacje z funkcjonowaniem domów kultury, preferencjami nauczycieli, letnimi galami disco polo, wielkością, ciężarem instrumentów i badaniami fokusowymi stacji radiowych, przymierzających się do zmiany profilu muzycznego. Zamiast poziomów mikro i makro mamy, dłuższe lub krótsze sieci, mniej lub bardziej stabilne połączenia między jedną lokalną interakcją a inną, większą lub mniejszą liczbę mediatorów i pośredników (Latour 2011: 166), a „kiedykolwiek ktoś mówi o »systemie«, »cechach globalnych«, »strukturze«, »społeczeństwie«, »imperium«, »ekonomii światowej« czy »organizacji«, to pierwszą reakcją z zakresu ANT powinno być zapytanie: »W jakim budynku? W którym biurze? Jaki korytarz tam prowadzi? Którzy spośród badaczy o tym słyszeli? W jaki sposób zostało to zebrane?" (Latour 2010: 267-268).

Pedagodzy analizujący kolektywy muszą zrewidować, co uznają za przedmiot swoich badań. Muszą być gotowi na pojawianie się paradoksalnych bytów i nieoczywiste relacje między nimi. Podążanie za aktorami tworzącymi kolektywy edukacyjne, badanie procesów translacji (Latour 2010; Law 2014), a więc tego jak jedne rzeczy zastępowane są przez inne (np. w jakie sposoby wartości są oddelegowywane do rzeczy, co się tu traci, co zyskuje?) może zaprowadzić w z pozoru niepedagogiczne miejsca. Odkrycie tych miejsc jest jednak kluczowe dla odpowiedzi na pytanie, dlaczego pewne sieci edukacyjnego sprawstwa są trwalsze od innych, dlaczego mimo dobrych intencji wychowawców szkoły wciąż „pełne” są nierówności. Pedagodzy jak socjologowie, „,którzy nie traktują maszyn i architektury równie poważnie co ludzi, nigdy nie znajdą rozwiązania problemu reprodukcji społecznej” (Law 2014: 230).

\section{Konkluzja}

W prezentowanym tekście starałem się zrehabilitować slogan dotyczący wychowania w kolektywie. Sposób, jaki wybrałem zakładał rozszerzenie rozumienia kluczowej kategorii Makarenki o wybrane wątki teorii aktora - sieci. W rzeczy samej chodziło o wskaza- 
nie tego, że kolektywy zawsze są więcej niż ludzkie, że są sieciami rozproszonego sprawstwa, że podlegają ciągłym zmianom, których tylko część daje się racjonalnie zaplanować, przewidzieć i że zmiany wywoływane są również przez czynniki pozaludzkie. Chodziło o pokazanie, że dyskursy nie są częścią innej rzeczywistości niż bakterie, samochody i tablice interaktywne, że kolektywy są jednocześnie symboliczne i materialne. I jeśli udało mi się pokazać, że tak rozumiana kolektywność jest cechą każdej sytuacji edukacyjnej, to już teraz nic nie stoi na przeszkodzie, żeby wznieść pedagogiczny okrzyk: „Przez kolektyw, w kolektywie, dla kolektywu!"

\section{Literatura}

Abriszewski K. (2013), Kulturowe funkcje filozofowania. Torun, Wydawnictwo Uniwersytetu Mikołaja Kopernika.

Abriszewski K. (2010), Splatajac na nowo ANT. Wstęp do Splatajac na nowo to, co społeczne. W: Latour B., Splatając na nowo to, co społeczne. Wprowadzenie do teorii aktora-sieci. Przeł. A. Derra, K. Arbiszewski. Kraków, UNIVERSITAS.

Abriszewski K. (2012), Poznanie, zbiorowość, polityka. Analiza teorii aktora-sieci Bruno Latoura. Kraków, UNIVERSITAS.

Abriszewski K., Chutorański M., Makowska A., Sokołowski-Zgid M., Szwabowski O. (2017), Pedagogika (i) rzeczy. Zapis debaty panelowej. W: D. Kubinowski, M. Chutorański (red.), Pedagogika jako humanistyczno-społeczna nauka stosowana: konsekwencje metodologiczne. Kraków, Oficyna Wydawnicza „Impuls”.

Bińczyk E. (2007), Obraz, który nas zniewala. Wspótczesne ujęcia języka wobec esencjalizmu i problemu referencji. Kraków, UNIVERSITAS.

Bińczyk E. (2012), Technonauka w społeczeństwie ryzyka. Filozofia wobec niepożądanych następstw praktycznego sukcesu nauki. Toruń, Wydawnictwo Naukowe Uniwersytetu Mikołaja Kopernika.

Chutorański M. (2016), Nie(tylko)ludzka pedagogika? W: K. Węc, A. Wierciński (red.), Ryzyko jako warunek rozwoju. Transformatywne aspekty hermeneutyki edukacji. Torun, Wydawnictwo Adam Marszałek.

Chutorański M. (2015), Urządzenie (edukacyjne): sieci, dyskursy, ludzie, nie-ludzie, „Teraźniejszość - Człowiek - Edukacja”, 4 (72).

Chutorański M. (2017), W stronę nie-antropocentrycznej ontologii tego, co edukacyjne (w druku).

Chutorański M., Makowska A. (2016), Pedagogika rzeczy nie(tylko)konsumowanych. „Parezja”, $1(5)$.

Jaworska-Witkowska M., Kwieciński Z. (2011), Nurty pedagogii. Naukowe, dyskretne, odlotowe. Kraków, Oficyna Wydawnicza „Impuls”.

Kamiński A. (1948), Pedagogika Antoniego Makarenki. Warszawa, Chłopska Spółdzielnia Wydawnicza.

Kirsh D. (2013), Poznanie ucieleśnione i magiczna przyszłość projektowania interakcji. Przeł. Ł. Afeltowicz. „AVANT”, 2 (IV).

Krajewski M. (2013), Przeciwzłożoność. Polityki prostoty „Studia socjologiczne”, 4. 
Kwa Ch. (2002), Romantic and Baroque Conceptions of Wholes in the Science. W: J. Law, A. Mol (red.), Complexities. Social Studies of Knowledge Practices. Durham-London, Duke University, Press.

Latour B. (2011), Nigdy nie byliśmy nowocześni. Przeł. M. Gdula, Warszawa, Oficyna Wydawnicza.

Latour B. (2009), Polityka natury. Nauki wkraczają do demokracji. Przeł. A. Czarnecka, Warszawa, Wydawnictwo Krytyki Politycznej.

Latour B. (2010), Splatajac na nowo to, co społeczne. Wprowadzenie do teorii aktora-sieci. Przeł. A. Derra, K. Abriszewski. Kraków, UNIVERSITAS.

Law J. (2014), Uwagi na temat teorii aktora-sieci: wytwarzanie ładu, strategia i heterogeniczność, przeł. K. Abriszewski. W: E. Bińczyk, A. Derra (red.), Studia nad nauka i technologia. Wybór tekstów. Toruń, Wydawnictwo Naukowe Uniwersytetu Mikołaja Kopernika.

Makarenko A. (1988), Makarenko o wychowaniu. Wybór pism. Wybór i opracowanie A. Lewin, M. Bybluk. Warszawa, Wydawnictwa Szkolne i Pedagogiczne.

Mason M. (red.) (2008), Complexity Theory and the Philosophy of Education. West Sussex, WileyBlackwell.

Morrison K. (2008), Educational Philosophy and the Challenge of Complexity Theory W: M. Mason (red), Complexity Theory and the Philosophy of Education. West Sussex, Wiley-Blackwell.

Mills C.W. (2008), Wyobraźnia socjologiczna. Przeł. M. Bucholc. Warszawa, Wydawnictwo Naukowe PWN.

Nowak A.W. (2011), Podmiot, system, nowoczesność. Poznań, Wydawnictwo Naukowe Instytutu Filozofii Uniwersytetu Im. Adama Mickiewicza w Poznaniu.

Nowak A.W. (2016), Wyobraźnia ontologiczna. Filozoficzna (re)konstrukcja fronetycznych nauk społecznych. Poznań, Wydawnictwo Naukowe UAM.

Prigogine I., Stengers I. (1990), Z chaosu ku porządkowi. Nowy dialog człowieka z przyroda. Przeł. K. Lipszyc. Warszawa, Państwowy Instytut Wydawniczy.

Urry J. (2005), Global complexity. Cambridge-Malden, Polity Pressin-Blackwell Publishing. 